\title{
EXOGENOUS HYDROGEN PEROXIDE INDUCES AN ANTIOXIDATIVE DEFENSE SYSTEM AGAINST DROUGHT STRESS IN SOYBEAN [Glycine max (L.) Merr.] CROPS
}

\author{
S. Darmanti ${ }^{1 *}$, E. D. Hastuti ${ }^{1}$ and S. W. A. Suedy ${ }^{1}$ \\ Department of Biology, The Faculty of Science and Mathematics, Diponegoro University Semarang, Indonesia \\ *Corresponding author’s email: darmantisri@yahoo.co.id
}

\begin{abstract}
Environmental stress generates an increased synthesis of Reactive Oxygen Species (ROS). The accumulation of ROS in the large amount causes the occurrence of oxidative stress but also stimulates the activation of an antioxidative defense system. The interaction of responses towards double stresses in the plant could promote negative effect because there was an accumulation of negative influences from both stresses, or contrarily increase the resistance of the plant toward stress. Hydrogen peroxide $\left(\mathrm{H}_{2} \mathrm{O}_{2}\right)$ is the main molecule of ROS that is the most stable, which plays the role in the control of acclimatization and defense against stress. This research aimed to examine the effect of the application of exogenous $\mathrm{H}_{2} \mathrm{O}_{2}$ to the induction of antioxidative defense system on the soybean plants that get or that did not get drought stress and to define the optimum concentration of $\mathrm{H}_{2} \mathrm{O}_{2}$ that can induce maximum oxidative defense system. This research was conducted with Completely Randomized Designs (CRD) with two factors, including the concentration of $\mathrm{H}_{2} \mathrm{O}_{2}(0 \mathrm{mM}$, $0.5 \mathrm{mM}, 1 \mathrm{mM}$, and $2 \mathrm{mM}$, and water supply (watering and drought stress), with five replication for each treatment unit. The result concluded that the application of exogenous $\mathrm{H}_{2} \mathrm{O}_{2}$ induced the activation of oxidative defense system through the increased activity of enzymes i.e.superoxide dismutase (SOD), catalase (CAT), ascorbate peroxidase (APX), glutathione reductase (GR) and total phenol content. Soybean plants became more resistant to drought stress after the application of exogenous $\mathrm{H}_{2} \mathrm{O}_{2}$, shown by the unwithered leaves. The optimum concentration of $\mathrm{H}_{2} \mathrm{O}_{2}$ that can induce the oxidative defense system on the soybean cv. Grobogan was $1 \mathrm{mM}$.
\end{abstract}

Keywords: antioxidant, enzymes activity, environmental stresses, ROS.

https://doi.org/10.36899/JAPS.2021.1.0208

Published online August 26, 2020

\section{INTRODUCTION}

Soybean [Glycine max (L.) Merr. ] seed is an important food commodity in Indonesia, however, the efforts to increase production are constrained by various biotic and abiotic factors. Generally, the plantation of soybean is conducted in the early dry season, thus the drought stress becomes one of the abiotic constraints in the culture of soybean.

Under the normal conditions, plant synthesize a small amount of Reactive Oxygen Species (ROS) as a byproduct of the metabolic pathway that serve as the second messenger in the response of plants toward the environmental condition (Apel and Hirt, 2004; Hung et al. 2005). Various environmental stresses stimulate an increase in ROS production. High ROS concentration cause an occurrence of oxidative stress (Apel and Hirt, 2004; Gill and Tuteja, 2010; Sharma et al. 2012).There are several forms of ROS, such as superoxide $\left(\mathrm{O}_{2}{ }^{-}\right)$, perhydroxyl $\left(\mathrm{HO}_{2}{ }^{2}\right)$, hydroxyl $(\mathrm{OH})$, alkoxy (RO), singlet oxygen $\left({ }^{1} \mathrm{O}_{2}\right)$ and hydrogen peroxide $\left(\mathrm{H}_{2} \mathrm{O}_{2}\right)($ Gill and Tuteja, 2010). According to Slesak et al. (2007), $\mathrm{H}_{2} \mathrm{O}_{2}$ is the most stable ROS molecule to regulate the acclimatization, defense, and development processes of plant. $\mathrm{H}_{2} \mathrm{O}_{2}$ made by chemical factories can be used for exogenous treatment. Exogenous $\mathrm{H}_{2} \mathrm{O}_{2}$ treatment at 1.5
$\mathrm{mM}$ increases cucumber seedling tolerance to drought (Sun et al., 2016). Whereas Khan et al. (2018) reported that exogenous $\mathrm{H}_{2} \mathrm{O}_{2}$ at $0.5 \mathrm{mM}$ caused an increase in proline content, antioxidant enzyme activity and growth of tomato (Lycopersicum esculentum) plants .

The plant is the sessile organism that naturally possesses a self-defense mechanism toward various environmental stress such as the antioxidative defense system. The defense systems include antioxidant enzymes such as superoxide dismutase (SOD), catalase (CAT), ascorbate peroxidase (APX), and glutathione reductase (GR) as well as non-enzymatic antioxidants such as ascorbic acid, phenol, carotenoid, proline, and glutathione. An antioxidant can scavenge ROS and regulate it in the safe amount range. Activation of the antioxidative defense system is triggered by the high accumulation of ROS (Gill and Tuteja, 2010; Akinson and Urwin 2012). Several studies have shown that soybean plants get multiple stress that is purple nutsedge interference and drought will increase the antioxidant compounds accumulation, namely ascorbic acid, glutathione and phenolic, as well as an increase CAT, APX and SOD enzymes activity, increase proline accumulation, increase ROS accumulation in the form of superoxide and hydrogen peroxide, increase phenylalanine ammonia-lyase (PAL) activity and changes 
of phenolic acids composition (Darmanti et al. 2016, 2017, 2018). PAL is a key enzyme that deflecting the primary metabolic pathway (the shikimic pathway) to the secondary metabolic pathway (phenylpropanoid pathway) (Khan et al., 2011).

The responses of plants toward various environmental stresses are central, thus enable the occurrence of the interaction of responses to various stresses. According to Velazquez et al. (2011), the response toward various forms of stresses could be overlapping or became one in the form of a signal element of ROS or $\mathrm{Ca}_{2}{ }^{+}$or both. Double stresses could increase the negative impact on the plants, thus the impact could far exceed the total negative impact caused by all stress factors that affect it. In certain cases, plants that are initially exposed to a single stress factor could improve its resistance toward another stress that arises later (Alexieva et al. 2003; Li and Gong, 2011; Akinson et al. 2012). Allelochemistry from the extract of sunflower increases the tolerance of rice crops toward salinity (Farooq et al. 2011). According to Alexieva et. al. (2003), the interaction of responses that occur in plants causes the response of plants to the first stress can cause an increase or decrease in tolerance of plants to the second stress.

The objective of this research was to study the effect of exogenous $\mathrm{H}_{2} \mathrm{O}_{2}$ application toward the induction of antioxidative defense system in soybean that received drought stress and to determine the optimum concentration of $\mathrm{H}_{2} \mathrm{O}_{2}$ that induced the maximum oxidative defense system.

\section{MATERIALS AND METHODS}

Materials and equipment: Soybean [Glycine max (L.) Merr. ] cv. Grobogan seeds were produced by BALITKABI Malang, East Java. The main equipment was centrifuge with a refrigerator and a spectrophotometer (Shimizu UV mini 1240).

Research design: This research design was Complete Randomized Design (CRD) with two factors, i.e. $\mathrm{H}_{2} \mathrm{O}_{2}$ concentration $\left(\mathrm{H}_{0}=0 \mathrm{mM}, \mathrm{H}_{1}=0.5 \mathrm{mM}, \mathrm{H}_{2}=1 \mathrm{mM}\right.$ and $\mathrm{H}_{3}=2 \mathrm{mM}$ ) and level of water supply (watering and drought). Each treatment unit contained five replications.

\section{a. Methods}

Planting and treatment: The experiment was conducted in the greenhouse built with $14 \%$ of UV plastic. The seed of soybean was selected according to the size homogeneity. Plastic pots with a diameter of $25 \mathrm{~cm}$ were filled with $1.5 \mathrm{~kg}$ of growing media consisted of a mixture of soil, burnt husks, and manure. Water volume was detremineted based on the field capacity and the drought stress condition according to The Fraction of Transpirable Soil Water (FTSW) method of Heinemann et al. (2011). Basic fertilizer i.e. $1 \mathrm{~g}$ TSP, $0.5 \mathrm{~g} \mathrm{KCL}$ and $0.3 \mathrm{~g}$ ZA added to each pot (Darmanti et al. 2018). Three soybean seeds were grown in each pot. One seedling was selected each pot based on the homogenity of seedling high and leaves number after one week. Watering treatment was conducted every day to maintain the condition of growth media field capacity. $\mathrm{H}_{2} \mathrm{O}_{2}$ treatment sprayed on the leaves surface four weeks after planting accorded to the treatment concentrations. It conducted for three days consecutively in the morning. In the drought stress treatment watering stoped until the value of the fraction of transpirable soil water (FTSW) reaches 0.25 $\%$ and it is maintained until harvest at the end of the vegetative growth phase. Plant control remains watered. Further, the leaves were harvested for analysis of the observed parameters.

\section{Determination of endogenous ROS accumulations}

Superoxide ( $\left.\mathbf{O}_{2}{ }^{-}\right)$. Samples of soybean leaves as much as $0.5 \mathrm{~g}$ were inserted into a test tube, then added with 7 $\mathrm{ml}$ of $50 \mathrm{mM}$ phosphate buffer $\mathrm{pH} 7.8$ which contained $0.05 \% \mathrm{NBT}$ and $10 \mathrm{mM} \mathrm{NaN}$. The samples were incubated for 5 minutes in the darkroom at room temperature. The solution was taken $2 \mathrm{ml}$ and then heated in a water bath for 10 minutes at temperature $85^{\circ} \mathrm{C}$, followed by cool it down in an ice bath for 5 minutes. Absorbance was read at $\lambda 589 \mathrm{~nm}$. The level of $\mathrm{O}_{2}$ was expressed in absorbance / $\mathrm{g}$ fresh weight of the sample (A /g) (Malecka et al. 2014; Darmanti et al. 2016)

Hydrogen peroxide $\left(\mathrm{H}_{2} \mathrm{O}_{2}\right)$. Sample of soybean's fresh leaves as much as $0.5 \mathrm{~g}$ was destroyed by a mortar in liquid nitrogen and then homogenized with $5 \mathrm{ml}$ TCA $0.1 \%$ in cold conditions, then centrifuged with the speed of $12,000 \mathrm{~g}$ for $15 \mathrm{~min}$ at $4^{\circ} \mathrm{C}$, the supernatant was used as an extract $\mathrm{H}_{2} \mathrm{O}_{2}$. The reaction mixture consisted of 0.5 $\mathrm{ml}$ of the supernatant, $0.5 \mathrm{~mL}$ of $10 \mathrm{mM}$ phosphate buffer pH 7 and $1 \mathrm{ml}$ solution of KI $1 \mathrm{M}$. The absorbance of the solution was determined at $\lambda 390 \mathrm{~nm}$. For the blank solution, a supernatant was replaced with $0.1 \%$ TCA. The content of $\mathrm{H}_{2} \mathrm{O}_{2}$ was determined the $\mathrm{H}_{2} \mathrm{O}_{2}$ standard curve (Bouazizi et al. 2007) modified by Darmanti et al. 2016).

\section{Determination of antioxidative enzymes activity}

Enzymes extraction. The extraction of enzymes referred to the protocol of Jiang and Zhang (2002) with modification. Fresh soybean leaves as much as $0.5 \mathrm{~g}$ was mashed in liquid nitrogen. The dissolved enzymes were extracted by homogenizing the mashed leaves in $10 \mathrm{~mm}$ $\mathrm{mM}$ potassium phosphate buffers $(\mathrm{pH} 7.0)$ containing 1 $\mathrm{mM}$ EDTA and $1 \%$ polyvinylpyrrolidone (PVP). In the extraction of APX, $1 \mathrm{mM}$ of ascorbic acid was added. The homogenates were centrifuged at the speed of 15,000 for 20 minutes at $4^{\circ} \mathrm{C}$ temperature. The resulted supernatant was the extract of enzymes used to analyze 
the enzyme activities. The amount of total protein was determined with the Bradford (1976) method.

SOD Activity. The SOD activity was examined by monitoring the inhibition of photochemistry reduction of nitroblue tetrazolium (NBT) based on the protocol of Jiang and Zhang (2002) with some modification. Three $\mathrm{ml}$ of reaction solution (consisted of $2.35 \mathrm{ml}$ buffer

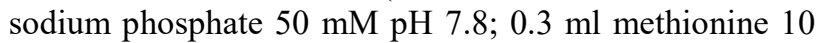
$\mathrm{mM}$; $0.1 \mathrm{ml}$ NBT $33 \mu \mathrm{M} ; 0.05 \mathrm{ml}$ riboflavin $0.0033 \mathrm{mM}$; $0.2 \mathrm{ml}$ EDTA $0.66 \mathrm{mM}$ ) added with $200 \mu \mathrm{l}$ buffers and $200 \mu$ enzyme extract. The decrease in absorbance was measured at $\lambda 560 \mathrm{~nm}$. One unit of SOD activity was defined as the amount of enzyme required to promote the inhibition of NBT reduction reaction by $50 \%$ compared to the reduction speed of NBT by the absence of enzyme seen from the absorbance at the same wavelength.

CAT activity. The CAT activity measured by the protocol that had been implemented by Jiang and Zhang (2002) with some modifications. Enzyme activity was expressed as the decrease in $\mathrm{H}_{2} \mathrm{O}_{2}$, determined by measure the decrease of $\mathrm{H}_{2} \mathrm{O}_{2}$ absorbance at $\lambda 240 \mathrm{~nm}$ for one minute. The CAT activity was calculated as the amount of $\mathrm{H}_{2} \mathrm{O}_{2}(\mu \mathrm{mol})$ that got degraded in one minute per mg of protein. The CAT activity was stated as $\mathrm{U} / \mathrm{mg}$ protein. The solution for the reaction consisted of 2.8

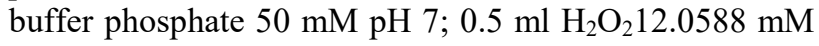
and $0.2 \mathrm{ml}$ enzyme extract.

APX activity. The APX activity measure by Nakano and Asada's method as in Jiang and Zhang (2002) with some modifications. The determination of APX activity was based on the oxidized ascorbic acid, which was shown by the decrease in absorbance at $\lambda 290 \mathrm{~nm}$ for one minute. One $\mathrm{ml}$ of the reaction solution consisted of $50 \mathrm{mM}$ buffer potassium phosphates ( $\mathrm{pH} 7.0) ; 0.5 \mathrm{mM}$ ascorbic

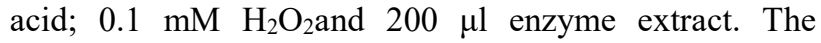
reaction started by addition of $\mathrm{H}_{2} \mathrm{O}_{2}$.

GR activity. The GR activity determinated by the protocol used by Elavarthi and Martin (2010) with some modifications. The GR activity determined according to the increase of absorbance value in the reaction of DTNB reduction to TNB by GSH in the reaction mixture at $\lambda$ $415 \mathrm{~nm}$ for 3 minutes. The reaction solution consisted of $810 \mu \mathrm{l}$ buffer phosphate $50 \mathrm{mM} \mathrm{pH} 7.8$ that contained EDTA $2 \mathrm{mM} ; 375 \mu \mathrm{l}$ DNTB $0.75 \mathrm{mM} ; 150 \mu \mathrm{l}$ NADPH $0.1 \mathrm{mM} ; 150 \mu \mathrm{l} \mathrm{GSSG}$ (L-glutathione oxidized) $1.0 \mathrm{mM}$ and $15 \mu \mathrm{l}$ of enzyme extract.

\section{Determination of non-enzymatic antioxidants accumulations.}

Extraction. The extraction of ascorbic acid utilized the method of Ozer in Panda and Patra (2007) with modification. $0.5 \mathrm{gr}$ of the sample was crushed in liquid nitrogen, homogenized with $3 \mathrm{ml}$ of sulfosalicylic acid
$7 \%$, then centrifuged at the speed of $10,000 \mathrm{~g}$ for 10 minutes producing supernatant as the extract.

Ascorbic acid. The concentration of ascorbic acid was determined by the method of Ozer in Panda and Patra (2007). The reaction mixture consisted of $2 \mathrm{ml} \mathrm{Na}$ molibdate $2 \%, 2 \mathrm{ml} \mathrm{H}_{2} \mathrm{SO}_{4} 0.15 \mathrm{M}, 1 \mathrm{ml} \mathrm{NaHPO} 415 \mathrm{mM}$ and $1 \mathrm{ml}$ extract incubated for 40 minutes at $60^{\circ} \mathrm{C}$ temperature, then cooled down, centrifuged for 10 minutes at the speed of $3.000 \mathrm{~g}$. The absorbance of the supernatant was measured at $\lambda 660 \mathrm{nM}$. The concentration of ascorbic acid was determined by the standard curve.

Total phenol. The total phenol measure based on the protocol of Rameshkumar and Sivasuda (2012) with modification. 0.5 gr of leaf sample was mashed in liquid nitrogen, homogenized with $2.5 \mathrm{ml}$ methanol, filtered with filter paper, then the filtrate was set to $5 \mathrm{ml}$ by adding methanol and used as the extract. The reaction mixture consisted of $20 \mu \mathrm{l}$ extracts, $1.58 \mathrm{ml}$ of distilled water, and $100 \mu \mathrm{l}$ folic acid, incubated for 8 minutes, added with $300 \mu \mathrm{l}$ sodium carbonate $7.5 \%$, then incubated again for 30 minutes at $30^{\circ} \mathrm{C}$ temperature. The absorbance was measured at $\lambda 769 \mathrm{~nm}$. The concentration of total phenol was based on the standard curve.

Proline. The of proline concentration determinated based on the protocol of Bates et al. (1973) with modification. Fresh leaves as much as $0.15 \mathrm{~g}$ was crushed in liquid nitrogen, homogenized with $3 \mathrm{ml}$ of sulfosalicylic acid $3 \%$ then centrifuged at the speed of $8.000 \mathrm{~g}$ at $4^{\circ} \mathrm{C}$ temperature for 10 minutes. The supernatant was then proline extract. $2 \mathrm{ml}$ of extract was added with $2 \mathrm{ml}$ ninhydrin acid and $2 \mathrm{ml}$ of glacial acetic acid 100\%, incubated in the water bath at $100^{\circ} \mathrm{C}$ temperature for 60 minutes. The reaction was ceased by inserting icebath, then added with $4 \mathrm{ml}$ toluene and vortex, then left until the toluene was secluded. The absorbance of proline was measured at $\lambda 520 \mathrm{nM}$. The concentration of proline was determined by the standard curve of proline.

b. Data Analysis: Quantitative data obtained from this research were analyzed using an analysis of variant (ANOVA) to determine the treatment effect toward measured parameters. Besides, the Duncan's Multiple Range Test (DMRT) was used to determine the significant differences between treatments at $95 \%$ confidence level.

\section{RESULT AND DISCUSSION}

The result showed that the application of exogenous $\mathrm{H}_{2} \mathrm{O}_{2}$ followed by watering increased the accumulation of $\mathrm{O}_{2}^{-}$, while in the treatment followed by drought stress caused the decrease of $\mathrm{O}_{2} \cdot-$ accumulation. The decrease was caused by the conversion of the 
produced $\mathrm{O}_{2}{ }^{--}$to $\mathrm{H}_{2} \mathrm{O}_{2}$ directly or through the dismutation reaction catalyzed by SOD. It was also proven by the increased accumulation of endogenous $\mathrm{H}_{2} \mathrm{O}_{2}$ in the soybean that followed by drought or watering. The accumulation of $\mathrm{H}_{2} \mathrm{O}_{2}$ in the soybean with drought stress treatment was more than the soybean with watering treatment due to the increased synthesis of $\mathrm{H}_{2} \mathrm{O}_{2}$ caused by the secondary stress (Table 1.)

Table 1. The accumulation of $\mathrm{O}_{2}^{--}$and endogenous $\mathrm{H}_{2} \mathrm{O}_{2}$ in soybean [Glycine max (L.) Merr.] cv. Grobogan leaves as the effect of exogenous $\mathrm{H}_{2} \mathrm{O}_{2}$ application followed by watering or drought stress.

\begin{tabular}{|c|c|c|c|c|c|}
\hline \multirow{2}{*}{ Accumulation of ROS } & \multirow{2}{*}{ Treatment } & \multicolumn{4}{|c|}{ A concentration of $\mathrm{H}_{2} \mathrm{O}_{2}$ by Treatment } \\
\hline & & $\mathbf{0} \mathbf{~ m M}$ & $0.5 \mathrm{mM}$ & $1 \mathrm{mM}$ & $2 \mathrm{mM}$ \\
\hline \multirow{2}{*}{$\mathrm{O}_{2} \cdot{ }^{-}(\mathrm{Abs} / \mathrm{g})$} & Watering & $0.08^{\mathrm{e}}$ & $0.11^{\mathrm{e}}$ & $0.12^{\mathrm{e}}$ & $0.18^{\mathrm{d}}$ \\
\hline & Drought & $0.45^{\mathrm{a}}$ & $0.37^{b}$ & $0.27^{\mathrm{c}}$ & $0.23^{\mathrm{c}}$ \\
\hline \multirow{2}{*}{$\mathrm{H}_{2} \mathrm{O}_{2}(\mu \mathrm{mol} / \mathrm{g})$} & Watering & $2.42^{\mathrm{e}}$ & $3.71^{\mathrm{d}}$ & $5.76^{\mathrm{c}}$ & $6.06^{\mathrm{c}}$ \\
\hline & Drought & $7.39^{\mathrm{b}}$ & $9.67^{\mathrm{a}}$ & $9.62^{\mathrm{a}}$ & $9.66^{\mathrm{a}}$ \\
\hline
\end{tabular}

- $\quad$ Numbers followed by different letters on the same parameters showed a significant difference with the Duncan Multiple Test at the level of $95 \%$. Each treatment was applied with 5 replications.

The treatment of exogenous $\mathrm{H}_{2} \mathrm{O}_{2}$ concentration $0.5 \mathrm{mM}$ on the soybean crops which followed by watering caused the increase of SOD activity, but at a higher concentration of $\mathrm{H} 2 \mathrm{O} 2$, the SOD activity was decreased. Whereas for soybeans crops which followed by drought stress, SOD activity increased in $\mathrm{H}_{2} \mathrm{O}_{2}$ treatment concentrations of $0.5 \mathrm{mM}$ and $1 \mathrm{mM}$, and on higher concentrations, SOD activity decreased. Soybeans treated with $\mathrm{H}_{2} \mathrm{O}_{2}$ at the same concentration, SOD activity was higher in that it did not get drought-stressed than soybeans that received drought stress.

The CAT activity was increased on all treatments. The CAT activity on the soybean crops that got drought stress was generally higher than that got watering. The APX activity was increased on every treatment combination of watering and drought. The APX activity was higher in the soybean crops that got watering than that got drought stress. The GR activity in the soybean that got watering was increased in the $\mathrm{H}_{2} \mathrm{O}_{2}$ treatment with a concentration of $0.5 \mathrm{mM}$ and $1 \mathrm{mM}$, while in the soybean crops that got drought stress the GR activity was increased at all $\mathrm{H}_{2} \mathrm{O}_{2}$ concentration. The GR activity was higher in the soybean crops that got drought stress than that got watering (Table 2.).The increased activity of GR also encountered in cucumber (Cucumis sativus L.) which was treated with $\mathrm{H}_{2} \mathrm{O}_{2}$ and polyethylene glycol simultaneously (Liu et al., 2010).

Table 2. The activity of antioxidant enzymes of SOD, CAT, APX, and GR in the soybean [Glycine max (L.) Merr.] cv. Grobogan leaves as the effect of $\mathrm{H}_{2} \mathrm{O}_{2}$ application followed by watering or drought stress

\begin{tabular}{clcccc}
\hline The Concentration of enzymatic & \multirow{2}{*}{ Treatments } & \multicolumn{3}{c}{ Concentration of $\mathbf{H}_{2} \mathbf{O}_{2}$ Treatment } \\
\cline { 3 - 5 } Antioxidant & W $\mathbf{m M}$ & $\mathbf{0 . 5} \mathbf{~ m M}$ & $\mathbf{1} \mathbf{m M}$ & $\mathbf{2} \mathbf{~ m M}$ \\
\hline \multirow{2}{*}{ SOD (unit/g protein) } & Watering & $4.38^{\mathrm{b}}$ & $4.86^{\mathrm{a}}$ & $3.98^{\mathrm{c}}$ & $2.50^{\mathrm{e}}$ \\
& Drought & $1.39^{\mathrm{f}}$ & $2.18^{\mathrm{e}}$ & $3.51^{\mathrm{d}}$ & $1.37^{\mathrm{f}}$ \\
\multirow{2}{*}{ CAT $(\mu \mathrm{mol} / \mathrm{g}$ sample) } & Watering & $1.03^{\mathrm{e}}$ & $1.50^{\mathrm{d}}$ & $1.85^{\mathrm{c}}$ & $2.60^{\mathrm{b}}$ \\
& Drought & $0.91^{\mathrm{e}}$ & $2.29^{\mathrm{a}}$ & $3.31^{\mathrm{a}}$ & $3.56^{\mathrm{a}}$ \\
\multirow{2}{*}{ APX ( $\mu \mathrm{mol} / \mathrm{g}$ sample) } & Watering & $14.13^{\mathrm{c}}$ & $16.20^{\mathrm{b}}$ & $19.93^{\mathrm{a}}$ & $18.70^{\mathrm{a}}$ \\
& Drought & $8.71^{\mathrm{d}}$ & $8.22^{\mathrm{d}}$ & $15.21^{\mathrm{cb}}$ & $13.37^{\mathrm{c}}$ \\
\multirow{2}{*}{ GR $(\mu \mathrm{mol} / \mathrm{g}$ protein) } & Watering & $0.14^{\mathrm{e}}$ & $0.21^{\mathrm{c}}$ & $0.22^{\mathrm{c}}$ & $0.14^{\mathrm{e}}$ \\
& Drought & $0.18^{\mathrm{d}}$ & $0.26^{\mathrm{b}}$ & $0.35^{\mathrm{a}}$ & $0.21^{\mathrm{c}}$ \\
\hline
\end{tabular}

- Numbers followed by different letters on the same parameters showed a significant difference with the Duncan Multiple Test at the level of $95 \%$. Each treatment was applied with 5 replications.

The treatment of exogenous $\mathrm{H}_{2} \mathrm{O}_{2}$ that followed by watering increased the concentration of ascorbic acid, contrarily on the soybean crops that followed by drought stress had decrease the concentration of ascorbic acid. However, the soybean crops that got drought stress contain a higher concentration of ascorbic acid than the soybean crops that followed by watering. The application of $\mathrm{H}_{2} \mathrm{O}_{2}$ on the soybean crops both followed by watering as well as drought stress affected the concentration of total phenol, though generally, a concentration of total phenol on the soybean crops suffering drought stress was higher than the watered soybean. The concentration of proline increased as the effect of $\mathrm{H}_{2} \mathrm{O}_{2}$ application, and proline concentration in the soybean crops which suffering drought stress was higher than the soybean crops which that does not get drought stress (Table 3.) 
Table 3. The concentration of non-enzymatic antioxidant i.e. ascorbic acid, total phenol and proline in the soybean [Glycine $\max \left(\mathrm{L}\right.$.) Merr.) cv. Grobogan leaves as the effect of exogenous $\mathrm{H}_{2} \mathrm{O}_{2}$ application with watering or drought stress

\begin{tabular}{|c|c|c|c|c|c|}
\hline \multirow{2}{*}{$\begin{array}{c}\text { The Concentration of non- } \\
\text { enzymatic Antioxidant }\end{array}$} & \multirow{2}{*}{ Treatments } & \multicolumn{4}{|c|}{ Concentration of $\mathrm{H}_{2} \mathrm{O}_{2}$ Treatment } \\
\hline & & $\mathbf{0 ~ m M}$ & $0.5 \mathrm{mM}$ & $1 \mathrm{mM}$ & $2 \mathrm{mM}$ \\
\hline \multirow{2}{*}{ Ascorbic Acid $(\mu \mathrm{M} / \mathrm{g})$} & Watering & $3.73^{\mathrm{c}}$ & $4.05^{\mathrm{bc}}$ & $4.76^{\mathrm{b}}$ & $4.11^{\mathrm{bc}}$ \\
\hline & Drought & $6.36^{\mathrm{a}}$ & $6.40^{\mathrm{a}}$ & $4.81^{\mathrm{b}}$ & $4.30^{\mathrm{bc}}$ \\
\hline \multirow{2}{*}{ Phenol total $(\mathrm{mg} / \mathrm{g})$} & Watering & $75.09^{\mathrm{d}}$ & $82.57^{\mathrm{cd}}$ & $83.43^{\mathrm{c}}$ & $85.94^{\mathrm{c}}$ \\
\hline & Drought & $112.63^{\mathrm{b}}$ & $123.08^{\mathrm{a}}$ & $130.71^{\mathrm{a}}$ & $129.72^{\mathrm{a}}$ \\
\hline \multirow{2}{*}{ Proline $(\mu \mathrm{g} / \mathrm{g})$} & Watering & $38.42^{\mathrm{f}}$ & $41.26^{\mathrm{f}}$ & $76.60^{\mathrm{e}}$ & $77.68^{\mathrm{e}}$ \\
\hline & Drought & $149.86^{\mathrm{a}}$ & $133.89^{\mathrm{b}}$ & $117.86^{\mathrm{c}}$ & $101.82^{\mathrm{d}}$ \\
\hline
\end{tabular}

- Numbers followed by different letters on the same parameters showed a significant difference with the Duncan Multiple Test at the level of $95 \%$. Each treatment was applied with 5 replications.

The plant is considered to encounter stress when there is a decrease in the physiological processes thus it could not achieve the genotype potential (Pedrol et al., 2006). The response system towards stress in the plants occurs centrally. Stresses in plant increase the synthesis of ROS excessively which leads to oxidative stress, but on the other hand, it also induces the activation of an oxidative defense system. Thus, plants that undergo stresses could increase or decrease its resistance towards the following stresses (Alexieva et al. 2003; Li and Gong 2011; Velazquez et al. 2011).In this research, the ROS treatment in the form of exogenous $\mathrm{H}_{2} \mathrm{O}_{2}$ with a dose of $0.5 \mathrm{mM}, 1 \mathrm{mM}$ or $2 \mathrm{mM}$ was considered as the first stress, and then followed by drought stress as the second stress. As a control crop, some soybean plants remain watered.

The application of exogenous $\mathrm{H}_{2} \mathrm{O}_{2}$ at low concentration increased the SOD activity of soybean crops that got drought stress or got watered. In this condition, SOD acts as the first defense toward accumulated ROS by catalyzing the reaction of $\mathrm{O}_{2 .-}$ dismutations that are highly reactive become a more stable form that is endogenous $\mathrm{H}_{2} \mathrm{O}_{2}$ (Apel and Hirt, 2004). However, the treatment of exogenous $\mathrm{H}_{2} \mathrm{O}_{2}$ at the higher concentration that leads to the decrease of SOD was probably caused by the conversion of a large proportion of $\mathrm{O}_{2}$.- to $\mathrm{H}_{2} \mathrm{O}_{2}$ spontaneously. Furthermore, the endogenous $\mathrm{H} 2 \mathrm{O} 2$ formed would be detoxified to $\mathrm{H} 2 \mathrm{O}$ and $\mathrm{O} 2$ directly by CAT marked by the increase of CAT activity at all treatment. The detoxification of $\mathrm{H} 2 \mathrm{O} 2$ is also performed by APX through the cycle of ascorbate - glutathione. At that cycle, the $\mathrm{H}_{2} \mathrm{O}_{2}$ reduced by ascorbic acid with APX as a catalyst to produce malondialdehyde (MDA) and $\mathrm{H}_{2} \mathrm{O}$. The ascorbic acid could be re-formed from MDA by the utilization of nicotinamide adenine dinucleotide phosphate (NADPH) and MDA reductase catalyst (MADR). Besides, MDA can also experience spontaneous dismutation forming dihydro ascorbate (DHA). Ascorbic acid can also be reformed from DHA and reduced glutathione (GSH) by the catalyst of dihydroxy ascorbate reductase (DHAR) which will form oxidized glutathione (GSSG). Furthermore, the GSH will be reformed from GSSG by NADPH reducer and catalyst glutathione reductase (GR). In this study, the reduction of APX activity in the soybeans crops that got drought stress was caused by the increase GR activity in the ascorbate glutathione cycle. So does the decreasing concentration of ascorbic acid in the soybean crops that got drought stress since the ascorbate acid was continuously utilized in the cycle of ascorbate-glutathione to withstand stress, while the soybean crops that did not get drought stress cause the increase of ascorbate acid concentration.

The induction of the antioxidative defense system by the application of exogenous $\mathrm{H}_{2} \mathrm{O}_{2}$ was also shown by the increase of total phenol concentration. More accumulation of total phenol in the soybean that got drought stress than that got watering showed that the application of exogenous $\mathrm{H}_{2} \mathrm{O}_{2}$ increased the accumulation of endogenous $\mathrm{H}_{2} \mathrm{O}_{2}$ (Table 1), which would induce the synthesis of phenol as defense mechanism toward the second stress, in the form of drought stress. This result is consistent with the research by Darmanti et al. $(2016,2018)$ that drought stress on soybean increases the endogenous $\mathrm{H}_{2} \mathrm{O}_{2}$ and total phenol accumulation.

Proline is the amino acid that serves as an osmoregulator (Szabados and Savoure, 2009) and as a non-enzymatic antioxidant (Liang et al., 2013).. Generally, the accumulation of proline in the soybean that got drought stress was much higher than those that got watering treatment. However this study shows that the application of exogenous $\mathrm{H}_{2} \mathrm{O}_{2}$ on soybean that got drought stress treatment decreased the accumulation of proline, while application of exogenous $\mathrm{H}_{2} \mathrm{O}_{2}$ on soybean that got watering stress treatment increased the accumulation of proline. This indicates that in these multiple stress, the main role of proline is as an osmoregulator to decrease cell water potential thus allow the soybean to avoid water loss and maintain the water absorption rather than as scavenging of ROS. This result is appropriate to the opinion of Khan et al. (2011) that 
proline serves as the main osmoregulator to control cell osmotic pressure.

The application of exogenous $\mathrm{H}_{2} \mathrm{O}_{2}$ on the soybean followed by watering or drought stress decreased the width of stoma holes. It is considered as the defense mechanism of soybean toward stress mediated by ABA. According to Lim et al. (2015), various environmental stress stimulates more ABA synthesis, which will initiate the decrease of the width of stoma holes up to stoma closure. By the decrease of the width of stoma holes, the loss of water through transpiration is reduced. It was also proven by the soybean which was treated with $\mathrm{H}_{2} \mathrm{O}_{2}$ followed by drought stress, the width of the stoma holes was much smaller than the soybean that got watered (Table.4).

Table 4.The width of the stoma holes $(\mu)$ on the soybean crops [Glycine max (L.) Merr.] cv. Grobogan leaves as the effect of exogenous $\mathrm{H}_{2} \mathrm{O}_{2}$ application followed by watering or drought stress.

\begin{tabular}{lcccc}
\hline \multirow{2}{*}{ Treatments } & \multicolumn{4}{c}{ Concentration of $\mathbf{H}_{2} \mathbf{O}_{2}$ Treatment } \\
\cline { 2 - 5 } & $\mathbf{0 ~ m M}$ & $\mathbf{0 . 5} \mathbf{~ m M}$ & $\mathbf{1 ~ m M}$ & $\mathbf{2} \mathbf{~ m M}$ \\
\hline Watering & $5.31^{\mathrm{a}}$ & $5.21^{\mathrm{b}}$ & $5.14^{\mathrm{b}}$ & $5.20^{\mathrm{b}}$ \\
Drought & $4.00^{\mathrm{c}}$ & $3.66^{\mathrm{d}}$ & $3.75^{\mathrm{d}}$ & $3.67^{\mathrm{d}}$ \\
\hline
\end{tabular}

- $\quad$ Numbers followed by different letters showed a significant difference with the Duncan Multiple Test at the level of 95\%. Each treatment was applied with 5 replications.

The argument was emphasized by the fact that soybean crops that got drought stress after previously treated with $0 \mathrm{mM}$ exogenous $\mathrm{H}_{2} \mathrm{O}_{2}$ were withered, while the application of $0.5 \mathrm{mM}, 1 \mathrm{mM}$ and $2 \mathrm{mM}$ of $\mathrm{H}_{2} \mathrm{O}_{2}$ did not make the soybean crops withered (Figure 1.)

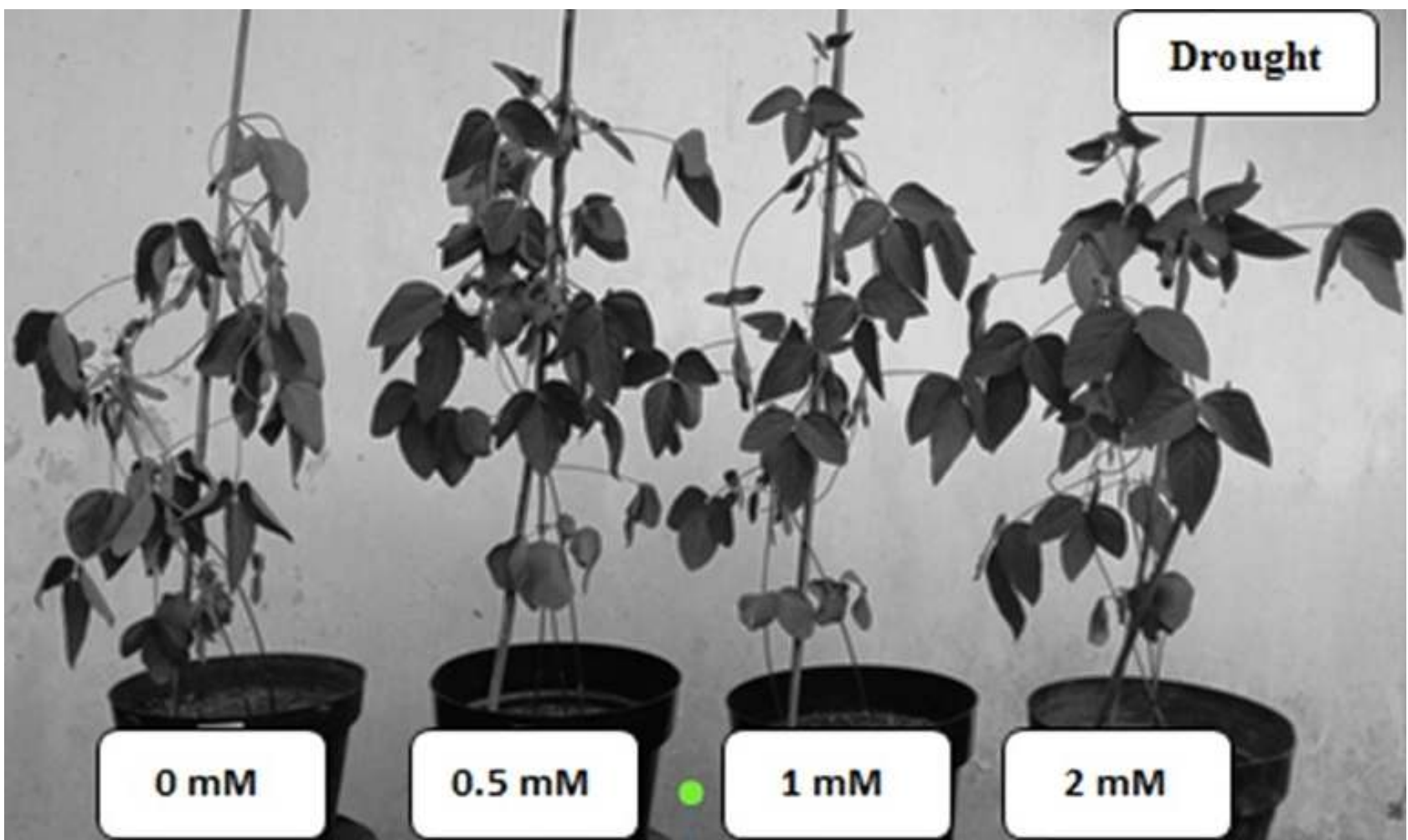

Figure 1. The soybean [Glycine max (L.) Merr.] cv. Grobogan crops 5 weeks after planting treated with exogenous $\mathrm{H}_{2} \mathrm{O}_{2}$ followed by drought stress treatment

Leaves of soybean crop after $\mathrm{H}_{2} \mathrm{O}_{2}$ application followed by watering did not achieve drought stress thus the leaves were not withered, as shown in Figure 3. Deng et al. (2012) also reported that exogenous $\mathrm{H}_{2} \mathrm{O}_{2}$ treatment at $0.5 \mathrm{mM}$ to $2.5 \mathrm{mM}$ has increased the growth of sweet potato roots and seedling, whereas at a concentration of 5 $\mathrm{mM}$ or more inhibited the growth of root and seedling. 


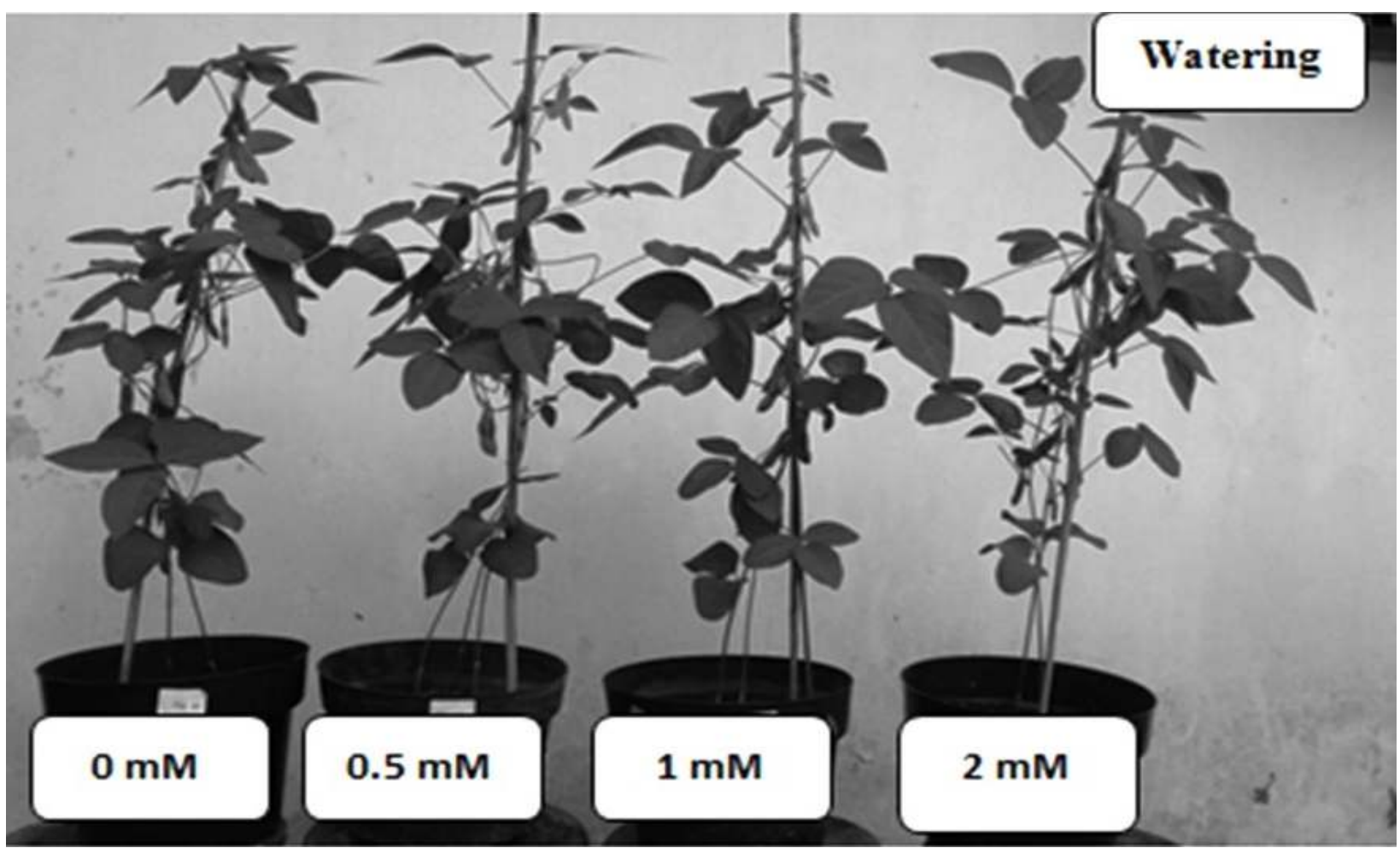

Figure 2. The soybean [Glycine $\max (\mathrm{L}$.) Merr.] cv. Grobogan crops 5 weeks after planting treated with exogenous $\mathrm{H}_{2} \mathrm{O}_{2}$ followed by watering treatment.

This study concluded that the sprinkling application on the leaves of soybean cv. Grobogan with exogenous $\mathrm{H}_{2} \mathrm{O}_{2}$ at the concentration of $0.5 \mathrm{mM}, 1 \mathrm{mM}$, and $2 \mathrm{mM}$ could induce the activation of an oxidative defense system so that soybean crops become more resistant to drought stress that ensues. That is by the increasing activity of antioxidative enzymes i.e. SOD, CAT, APX, and GR as well as increasing the concentration of non-enzymatic antioxidants in the form of total phenol, ascorbic acid and proline The induction of antioxidative defense causes soybean to be more resistant toward drought stress after the application of exogenous $\mathrm{H}_{2} \mathrm{O}_{2}$, shown by soybean leaves that were not withered. The optimum concentration of $\mathrm{H}_{2} \mathrm{O}_{2}$ that can induce the oxidative defense system in the soybean $\mathrm{cv}$. Grobogan was $1 \mathrm{mM}$.

Acknowledgment: Authors would like to thank the Faculty of Science and Mathematics Diponegoro University for providing research funding through PNBP Program in 2017 with the contract number: 1643 /UN7.5.8/PP/2017

\section{REFERENCES}

Atkinson N. J, and P.E.Urwin (2012). The interaction of plant biotic and abiotic stresses: from genes to the field. J Exp Bot. 63: 3523-3543.
Alexieva V., S. Ivanov, I. Sergiev and E. Karanov (2003). An interaction between stresses. Bulg J Plant Physiol. Special Issue.: 1-17.

Apel K. and H. Hirt (2004). Reactive oxygen species: metabolism, oxidative stress, and signal transduction. Annu Rev Plant Biol. 55: 373-399.

Bates L. S. (1973). Rapid determination of free proline for water stress - studies. Plant and Soil. 39: 205 $-207$.

Bouazizi H., H. Jouili and E. E. Ferjani (2007). Effects of copper Excess on growth, $\mathrm{H}_{2} \mathrm{O}_{2}$ production, and peroxidase activities in maize seedling (Zea mays L.). Pak J Biol Sci. 10: 751-756.

Bradford M. M. (1976). A rapid sensitive method for the quantitation of microgram quantities of protein utilizing the principle of protein-dye binding. Anal Biochem. 72: 248 - 254.

Darmanti S., Santosa, K. Dewi, and L. H. Nugroho (2016). Antioxidative defenses of soybean [Glycine max (L.) Merr. cv. Grobogan] against purple nutsedge (Cyperus rotundus L.) interference during drought stress. The J. Anim. Plant Sci. 26 (1): 225-232.

Darmanti S., Santosa, K. Dewi, and L. H. Nugroho (2017). Purple nutsedge (Cyperus rotundus L.) interference and drought effect on proline accumulation in soybean (Glycine max L.) Leaves. Adv Sci Lett. 23 (7): 6487 - 6489. 
Darmanti S., Santosa, K. Dewi, and L. H. Nugroho (2018). Reactive Oxygen Species Accumulations, Phenylalanine Amonialiase Activity and Phenolic Acid Composition of Soybean [Glycine $\max (\mathrm{L}$.$) Merr.] cv. Grobogan$ that Exposed to Multiple Stress of Purple Nutsedge (Cyperus rotundus L.) Interference and Drought. The J. Anim. Plant Sci. 28 (1): 244-252.

Deng X. P., Y. J. Cheng, X. B. Wu, S. S. Kwak, W. Chen, and A. Egriya (2012). Exogenous hydrogen peroxide positively influences root growth and metabolism in leaves of sweet potato seedlings. Aust J Crop Sci. 6 (11): 1572 - 1578.

Elavarthi S. and B. Martin 2010. Spectrophotometric assay for antioxidant enziymes in plant. Pp. 273 -280. In R. Sungkar (edt). Plant stress tolerance, method and protocols. Human Press. Springer. New York.

Farooq, M., M. Habib, A. U Rahman, A. Wahid and R. Munir (2011). Employing Aqueous Allelopathic Extracts of Sunflower in Improving Salinity Tolerance of Rice. J. Agric. Soc. Sci. 7 : 75-80.

Gill S.S. and N. Tuteja (2010). Reactive oxygen species and antioxidant machinery in abiotic stress. Plant Physiol Biochem. 48: 909-930.

Heinemann A. B., L.F. Stone, and N. K. Fageria (2011). Transpiration rate response to water deficit during vegetative and reproductive of upland rice cultivars. Sci Agric. 68: 24-30.

Hung S. H., C. W. Yu and C. H. Lin (2005). Hydrogen peroxide functions as a stress signal in plants. Bot Bull Acad Sin. 46: 1-10.

Jiang M. and J. Zhan (2002). Water stress-induced abscisic acid accumulation triggers the increased generation of reactive oxygen species and upregulates the activities of antioxidant enzymes in maize leaves. J Exp Bot. 53: 2401-2410.

Khan T A, M. Mazid and F. Mohammad (2011). Status of secondary plant products under stress. J Stress Physiol Biochem. 7: 75-98.

Khan. T. A., Q. Fariddudin. and M. Yusuf (2018). Effect of exogeneously sourced hydrogen peroxide treatment on growth, photosynthesis and antioxidant traits in two contrasting cultivar of tomato : A mode and concentration dependent study. Acad J Agric Research. 6 (1): 019 - 029.

Liang X., L. Zhang, S. K. Natarajan, and D. F. Becker (2013). Proline mechanisms of stress survival. Antioxid Redox Signal. 19 (9): 998 -1011.

Li G.Z. and M.Gong (2011). Mechanical stimulationinduce cross-adaptation in plants: An Overview. J. Plant Biol. 54: 358 - 364.
Lim C. W., W. Baek, J. Jung, J. Kim, and S. C. Lee (2015). The function of ABA in stomatal defense against biotic and drought stresses. Int $J$ Mol Sci. 16: 15251 -15270.

Liu Z. J., Y. K. Guo, and J. G. Bai (2010). Exogenous hydrogen peroxide changes antioxidant enzyme activity and protects ultrastructure in leaves of two cucumber ecotypes under osmotic stress. $J$ Plant Growth Regul. 29: 171 -183.

Malecka A., A. Piechakak, B. Zielinska, A. KutrowskaandB. Tomaszewski (2014). A response of the pie roots defense systems to the two element combinations of Metals $(\mathrm{Cu}, \mathrm{Zn}$, Cd, Pb). Acta Biochim. Pol. 61: 23 -28.

Panda S. K. and H. K. Patra (2007). Effect of salicylic acid potentiates cadmium-induced oxidative damage in Oryza sativa leaves. Acta Physiol Plant. 29: $567-575$.

Pedrol M. N., I. Gonzales, M. J. Reigosa (2006). Allelopathy and Abiotic Stress. In M.J. Reigosa, N.Pedrol and L. Gonzales. (eds.). Allelopathy: $A$ Physiological Process with Ecological Implication. Springer. The Netherlands.

Rameskhumar A and T. Sivasudha (2012). In vitro antioxidant and antibacterial activity of an aqueous and methanolic extract of Molligonudi caulis L. leaves. Asian Pac J Trop Biomed. 2012: S895 - S900. Doi : 10.1016/S2221 1691(12)60332-3.

Sharma P., A. B. Jha, R. S. Dubey, and M. Pessarakli (2012). Reactive oxygen species, oxidative damage, and antioxidative defense mechanism in the plant under stressful conditions. J Bot 2012: $1-26$.

Slesak I., M.Libik, B. Karpinska, S. Karpinski, Z. Miszalski (2007). The role of hydrogen peroxide in the regulation of plant metabolism and cellular signaling in response to environmental stresses. Acta Biochim Pol.. 54: 39-50.

Sun Y., H. Wang, S. Liu and X. Peng (2016). Exogenous application of hydrogen peroxide alleviates drought stress in cucumber seedling. S Afr J Bot. 106: 23-28.

Szabados L. and A. Savoure (2009). Proline: a multifunctional amino acid. Trend Plant Sci. 15 (2): $89-97$

Velazquez, S.F., R. R. Guerra and L.S. Calderon. (2011). Abiotic and Biotic Response Crosstalk in Plant .pp. 1-6. In A. Shanker (ed.) : Abiotic Stress Response in Plants - Physiological, Biochemical and Genetic Perspective. InTech China. Shanghai. 